\title{
FIELD WORK BETWEEN TUNUGDLIARFIK AND TASIUSSAQ
}

\section{H. Emeleus and D. Stephenson}

Major sinistral transcurrent faults cut the Igaliko nepheline syenites and associated dykes between Tunugdliarfik and Qôroq, and east of Qôroq (Emeleus \& Harry, in press, plate 4). Investigations by V. Poulsen, H. G. Scharbert and J. W. Stewart have shown that the Gardar dykes and earlier rocks are extensively faulted in a zone about $5 \mathrm{~km}$ wide, striking approximately east-west between Tunugdliarfik and Tasiussaq (fig. 3). In 1969 field work was undertaken to see whether it was possible to correlate the faults near Qagssiarssuk with those affecting the nepheline syenites of the South Qôroq Centre and the associated dykes. Some additional observations were also made on the dyke swarm south-west of Qagssiarssuk.

\section{Faulting}

After examination of the 1:20 000 geological maps, four of the numerous faults south and south-west of Qagssiarssuk were selected for further examination (faults numbered 1-4, fig. 3). In each instance the determinations of lateral movement were made using dykes which are distinctive by reason of their width, the size, shape and types of phenocrysts, and their weathering characteristics. A distinctive group of dykes consisting of 3-5 "big feldspar dykes" (ranging in width from 2 to $15 \mathrm{~m}$ ), together with several thick red-brown or orange-brown porphyritic trachytes (of general width $10-15 \mathrm{~m}$ ), was traced through the area and used at each fault. Little new information was obtained on the magnitude of the vertical movements on the faults; in each example the general direction of throw was known from the earlier investigations. Brief details for each fault follow.

Fault 1:2.4 km south-west of Qagssiarssuk the distinctive group of dykes is displaced sinistrally about $400 \mathrm{~m}$. The fault downthrows to the south. The throw is at least $100 \mathrm{~m}$ and may be more; this estimate is based on the height differences between the irregular base of the Eriksfjord sandstones south of the fault and the occurrence on its north side of a small area of conglomerate and grit at $220 \mathrm{~m}$ altitude, $2.5 \mathrm{~km}$ $\mathrm{S} 70^{\circ} \mathrm{W}$ of Qagssiarssuk. At this locality the fault consists of two or more parallel dislocations within a zone of alteration and crush about $50 \mathrm{~m}$ in width. The displacements given are aggregăte figures.

Fault 2: The course of this fault is marked by a fairly broad, gently curving zone of crush and discolouration up to $150 \mathrm{~m}$ in width. The group of dykes has a sinistral horizontal displacement of $5 \mathrm{~km}$ across this zone. The fault downthrows to the north. There is evidence that the fault consists of two or more parallel fractures along part of its length. 


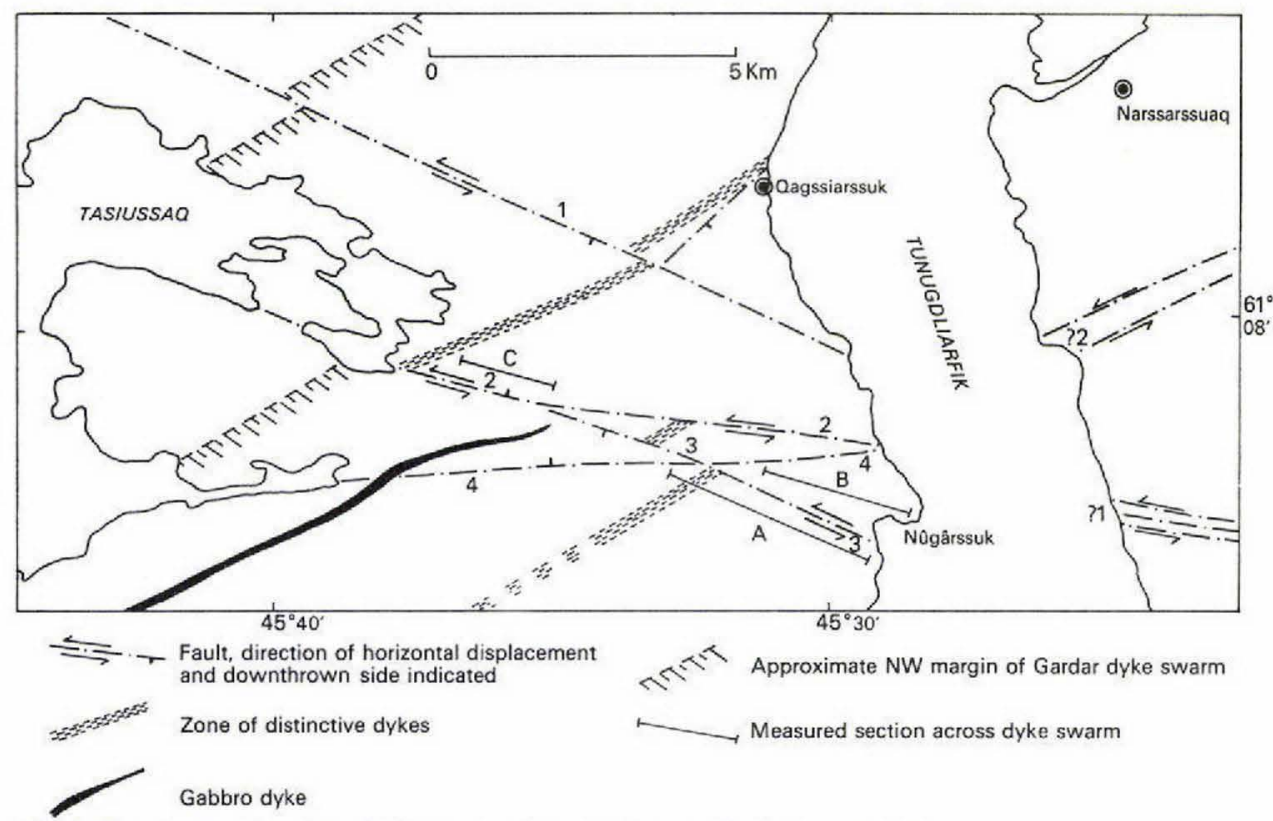

Fig. 3. Sketch map showing the fault zone between Tunugdliarfik and Tasiussaq.

Fault 3: Towards the east this fault is seen to merge with fault 2. It has a sinistral displacement of between $600 \mathrm{~m}$ and $800 \mathrm{~m}$; the downthrow is to the south. About 3 $\mathrm{km}$ WNW of the farm at Nûgârssuk the distinctive group of dykes is offset about $700 \mathrm{~m} ; 1.5 \mathrm{~km}$ WNW of the farm a single thick big feldspar dyke is displaced $800 \mathrm{~m}$, while on the south of the bay at Nûgârssuk a $12 \mathrm{~m}$ porphyritic trachyte is displaced $600 \mathrm{~m}$. In each instance the horizontal movement is in a sinistral sense.

Fault 4: This forms a well-defined east-west feature between the fjords. The fault downthrows by an unknown amount to the north but appears to have an insignificant lateral movement: towards the western end there is no mapped displacement of the thick gabbro dyke; near Nûgârssuk none of the Gardar dykes was noticeably offset although there were indications of crushing in porphyritic trachytes $1 \mathrm{~km} \mathrm{NW}$ of the farm. The available evidence indicates that this is a normal fault, probably younger than fault 3 .

From this examination of the individual faults, and from the offset of the northwest margin of the dyke swarm as mapped by earlier investigators (fig. 3), the total sinistral horizontal displacement across the fault zone is seen to be between $6 \mathrm{~km}$ and $6.5 \mathrm{~km}$. The greater part of this movement is accounted for by fault 2. Comparing these results with those obtained from the South Qôroq Centre and elsewhere in the Igaliko Complex (Emeleus \& Harry, in press), it is clear that no simple and straightforward correlation of the faults exists. A total sinistral horizontal movement of between $2.5 \mathrm{~km}$ and $3 \mathrm{~km}$ has been measured in the South Qôroq Centre between Tunugdliarfik and Qôroq, the greatest movement being slightly over $2 \mathrm{~km}$ on the 
northern fault. It is, however, significant that a total offset of between $6 \mathrm{~km}$ and $7 \mathrm{~km}$ may be calculated for the Gardar dykes in and near the South Qôroq Centre. This offset is obtained by combining the measured displacements along faults with the offset caused by the localised change in strike of members of the swarm, from the normal $\mathrm{N} 40-50^{\circ} \mathrm{E}$ into a direction $\mathrm{N} 20^{\circ} \mathrm{E}$ or even N-S (Emeleus \& Harry, in press, fig. 34). Tentative correlations across Tunugdliarik are indicated on fig. 3.

Table 1. Measurements on the Gardar dyke swarm near Qagssiarssuk

(a) (see fig. 3 for traverse localities)

\begin{tabular}{c|c|c|c|c}
\hline Traverse & $\begin{array}{c}\text { Distance at } \\
90^{\circ} \text { to swarm }\end{array}$ & $\begin{array}{c}\text { Number } \\
\text { of dykes }\end{array}$ & $\begin{array}{c}\text { Total thickness } \\
\text { of dykes }\end{array}$ & $\begin{array}{c}\text { Percent of } \\
\text { section }\end{array}$ \\
\hline A & $2800 \mathrm{~m}$ & 33 & $218 \mathrm{~m}$ & 7.8 \\
B & $2100 \mathrm{~m}$ & 27 & $127 \mathrm{~m}$ & 6.0 \\
C & $1100 \mathrm{~m}$ & 9 & $94 \mathrm{~m}$ & 8.5 \\
\hline
\end{tabular}

(b)

\begin{tabular}{c|c|c|c|c|c|c}
\hline Traverse & No. & $\begin{array}{c}\text { Trachytic dykes } \\
\text { Total thickness }\end{array}$ & No. & $\begin{array}{c}\text { Big Feldspar dykes } \\
\text { Total thickness }\end{array}$ & No. & $\begin{array}{c}\text { Basic dykes } \\
\text { Total thickness }\end{array}$ \\
\hline A & 21 & $125 \mathrm{~m}$ & 8 & $64 \mathrm{~m}$ & 4 & $29 \mathrm{~m}$ \\
B & 15 & $101 \mathrm{~m}$ & 4 & $19 \mathrm{~m}$ & 3 & $7 \mathrm{~m}$ \\
C & 7 & $74 \mathrm{~m}$ & 2 & $20 \mathrm{~m}$ & none & \\
\hline
\end{tabular}

The dyke swarm

The Gardar dyke swarm was mapped between Tunugdliarfik and Tasiussaq by several members of GGU. Details of the alkali feldspars from certain microsyenites have been published (Scharbert, 1966); descriptions of the NE extension of the swarm have also appeared (Bondam, 1955; Walton, 1965).

In 1969 the opportunity was taken to measure in detail the concentrations of dykes in three well-exposed sections across the swarm (lines A, B and C on fig. 3). Details of the measurements are given in table 1 . These show that the dykes make up between $6 \%$ and $8.5 \%$ of the measured sections; they also confirm that basic dykes are relatively rare, big feldspar dykes are fairly common and often over $10 \mathrm{~m}$ in thickness, and alkaline dykes are the most abundant.

\section{References}

Bondam, J. 1955: Petrography of a group of alkali-trachytic dyke rocks from the Julianehaab District, South Greenland. Bull. Gronlands geol. Unders. 7 (also Meddr Gronland 135, 2).

Emeleus, C. H. \& Harry, W. T. in press: The Igaliko nepheline syenite complex. General description. Bull. Gronlands geol. Unders. (also Meddr Gronland 186, 3).

Scharbert, H. G. 1966: The alkali feldspars from the microsyenitic dykes in southern Greenland. Miner. Mag. 35, 903-919.

Walton, B. J. 1965: Sanerutian appinitic rocks and Gardar dykes and diatremes, north of Narssarssuaq, South Greenland. Bull. Gronlands geol. Unders. 57 (also Meddr Gronland 179, 9). 